\section{MECHANICAL PROPERTIES OF WASTE PLASTIC BANNER FIBER REINFORCED CONCRETE}

\author{
Agustinus Agus Setiawana, Fredy Jhon Philipa, Eka Permanasarib \\ aDepartment of Civil Engineering, Pembangunan Jaya University, \\ Cendrawasih Raya B7/P, Bintaro Jaya, South of Tangerang, Banten, \\ Indonesia \\ bDepartment of Architecture, Pembangunan Jaya University, \\ Cendrawasih Raya B7/P, Bintaro Jaya, South of Tangerang, Banten, \\ Indonesia
}

Article history

Received

24 July 2017

Received in revised form

7 March 2018

Accepted

30 March 2018

Published online

1 August 2018

*Corresponding author agustinus@upj.ac.id

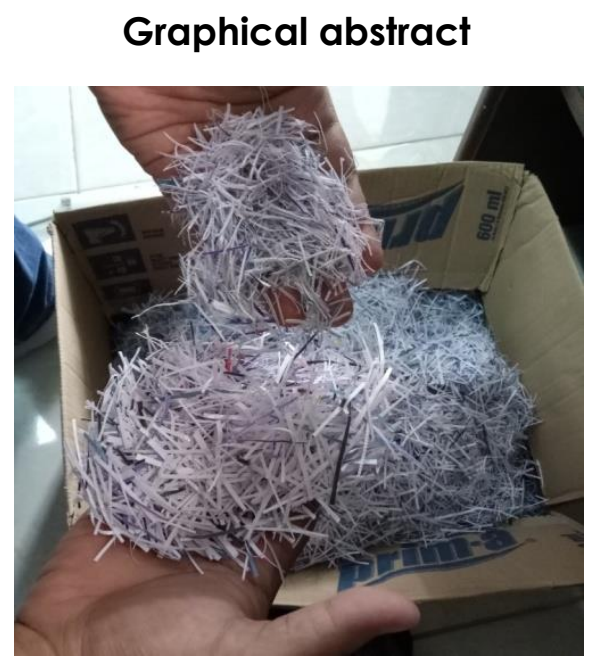

\begin{abstract}
The objective of this research is to determine the mechanical properties of the waste-plastic-banner-fiber reinforced concrete: compressive strength, splitting tensile strength, rupture modulus and modulus of elasticity. Concrete mixtures with different proportions of waste plastic banner fiber were produced and tested: $0 \%, 0.25 \%, 0.5 \%, 1.0 \%, 2.0 \%$ of waste plastic banner fiber. The tests showed that the addition of fiber by $0.5 \%$ from the total concrete volume will increase the splitting tensile strength by $14.28 \%$ and produce the modulus of elasticity as high as $23,025 \mathrm{MPa}$ (up to $12 \%$ from the normal mix) and yield the concrete compressive strength of $35.56 \mathrm{MPa}$ (up to $4.95 \%$ of the normal mixture). The rupture modulus will increase by $4.11 \%$ as the addition of $0.25 \%$ of waste plastic banner fiber.
\end{abstract}

Keywords: Compressive strength, splitting tensile strength, modulus of rupture, modulus of elasticity, waste plastic banner fiber

(c) 2018 Penerbit UTM Press. All rights reserved

\subsection{INTRODUCTION}

The economic growth in Indonesia has shown a steady increase in recent years, partly due to the advent of digital printing technology. Fabric banners used in the old days of printing technology become obsolete and are quickly replaced by felxy banner media derived from PVC, which is derivative of plastic materials. While flexy banners have advantages over fabric banners in terms of printing cost and durability, flexy banners pose a real problem to the environment because they can not be easily decomposed. However, unused plastic banners can be cut into small pieces to become plastic fibers.

Concrete which is widely used in the infrastructure construction, is a mixture of cement, fine aggregates such as sand, coarse aggregates such as gravel and water as reagents cement. It is known that concrete has a very high compressive strength, but it is weak in tensile strength. To improve its resistance to the tensile stress, sometimes fibers were added to the concrete mixture. Some types of fiber can be added in concrete mixtures such as bamboo fibers, steel fibers, plastic fibers and so on. The research of using fiber in concrete mixture was developed years ago. New experiments, such as Rao (2016), found that the addition of steel fibres to the concrete mixture increase the split and flexural strength of concrete up to $30 \%$ [1]. Hassan (2015) used steel fibers on one-way concrete slabs to increase stiffness, reduce crack width and its ductility [2]. The addition of volumetric ratio of steel fibers up to $0.4 \%$ of volume in concrete mixture increases the ultimate load of the slab between $20.7 \%$ to $56.9 \%$ and the addition of volumetric ratio of volumetric steel fiber up to $0.8 \%$ will increase the ultimate load between $48.3 \%$ to $90.5 \%$. 
The presence of steel fibers on one-way concrete plates is able to prevent cracking. Rao (2011) invesitaged the effect of adding polypropylene fiber to high beam concrete mixed with fly ash: adding polypropylene fibers of $0.5 \%$ to $1 \%$ increased the bending strength of the concrete beam between $15 \%$ and $20 \%$ and increased the concrete compressive strength from $15 \mathrm{MPa}$ to $25 \mathrm{MPa}$ [3]. This experiment showed that high beams with fibers and fly ash have more ductile failure compared to specimens without the addition of polypropylene fibers. Pawar (2014) used a mixture of iron slag waste (GGBS) and steel fibers in concrete mixtures used in rigid pavement. The optimal strength of optimum concrete mixture, which is $5.09 \mathrm{Mpa}$, is obtained by the addition of $30 \%$ GGBS material. Adding 1\% steel fiber into the mixture, could increase the bending capacity of concrete even further up to $7.87 \mathrm{MPa}$ (more than $50 \%$ of the normal strength) [4].

This research is part of a grand research scheme to understand the effect of using plastic materials in concrete mixture. The previous research done by Setiawan [5], investigated the use of Epoxy Polystyrene (EPS) grains as partial substitutes of fine aggregates in concrete mixture to produce lightweight concrete. The result showed that adding $5 \%$ EPS decreased the density of the concrete mixture to $20-25 \mathrm{~kg} / \mathrm{m}^{3}$ [5]. In this paper we investigate how the waste plastic banners can be used as the fiber material in manufacturing structural concrete to improve the mechanical properties of concrete, particularly its tensile strength. Additional advantage of using the waste plastic banners is to overcome the problem of plastic waste in the environment. Figure 1 shows the waste plastic banner that has been cut into small fibers, and will be used in this research as fibrous materials in the concrete mixture. So far no study has been reported on the use of waste plastic banners as fiber material in manufacturing structural concrete.

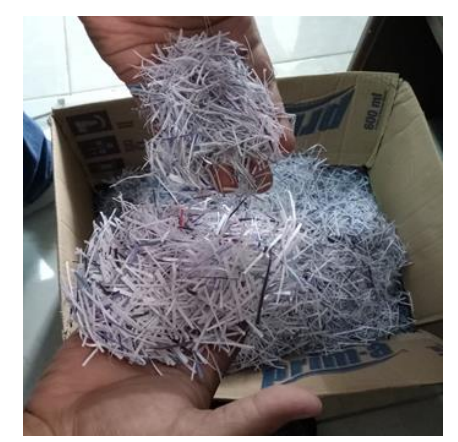

Figure 1 Waste plastic banner fiber

The objective of this research is to determine the mechanical properties of fiber reinforced concrete using waste plastic banner as the fibrous material. We measure the compressive strength, tensile splitting strength, modulus of rupture and modulus of elasticity. We made concrete mixtures added with waste plastic fibers with different proportions: $0 \%, 0.25 \%, 0.5 \%, 1.0 \%$,
$2.0 \%$. The concrete mixture without the addition of waste plastic banner fiber $(0 \%)$, serves as the reference point for the measurement. The addition of waste plastic banner fiber is expected to improve the mechanical properties of concrete, especially to increase its capabilty to resist tensile stress. The dimension of fiber is determined by its aspect ratio, i.e. the rasio between its length and its diameter. We limit the addition of the waste plastic fibers up to $2 \%$ of the volume of conceret mixture to avoid the reduced workability of the plain concrete. [6].

\subsection{METHODOLOGY}

To investigate the mechanical properties of waste plastic banner fiber concrete, especially for testing of compressive strength, tensile splitting strength, modulus of rupture and modulus of elasticity, we need to cast some specimens. To measure the compressive and splitting tensile strengths, we cast specimens of concrete cylinders with $10 \mathrm{~cm}$ in diameter and $20 \mathrm{~cm}$ in height which are tested at age of 7,14 and 28 days. To measure the modulus of elasticity, specimens of concrete cylinders with $15 \mathrm{~cm}$ in diameter and $30 \mathrm{~cm}$ in height are tested at the age of 28 days. Beam specimens are cast to investigate their modulus of rupture. The beams have $15 \mathrm{~cm}$ by $15 \mathrm{~cm}$ in section and $60 \mathrm{~cm}$ of length. The beam specimens are tested for modulus of rupture test at the age of 28 days.

\section{Materials}

We use materials with known properties that meet specific standards in this research. The cement used in this study, type-1 cement with Semen Gresik brand, meets the ASTM C150 / C150M - 17 "Standard Specification for Portland Cement" criteria. The fine aggregates used are derived from Galunggung sand, while the coarse aggregate used comes from Sudamanik, West Java. The water used must meet the minimum requirement as drinking water. The fibers used in this research come from unused PVC banners, cut into small fibers, $40 \mathrm{~mm}$ in length and $0.5 \mathrm{~mm}$ in diameter. Table 1 shows the natural properties of coarse aggregates and fine aggregates used in this research.

Table 1 Natural properties of coarse and fine aggregate

\begin{tabular}{lcc}
\hline Natural properties & $\begin{array}{c}\text { Fine } \\
\text { Aggregate }\end{array}$ & $\begin{array}{c}\text { Coarse } \\
\text { Aggregate }\end{array}$ \\
\hline Specific Gravity & 2.38 & 2.59 \\
\hline Unit Weight $\left(\mathbf{g r} / \mathrm{cm}^{3}\right)$ & 1.44 & 1.46 \\
\hline Materials $<75-\mu \mathrm{m}$ & $1.45 \%$ & $0.65 \%$ \\
\hline Absorption & $8.92 \%$ & $2.80 \%$ \\
\hline Fineness Modulus & 2.85 & 7.78 \\
\hline
\end{tabular}




\section{Compressive Strength Test}

ASTM C39/C39M - 09a "Standard Test Method for Compressive Strength of Cylindrical Concrete Specimens", is adopted to test the concrete compressive strength. The specimens with 7, 14 and 28 days of age are compressed with the Universal Testing Machine (UTM) under constant speed until failure occurs. The peak load which caused specimen failure was recorded. The concrete compressive strength is calculated using the following expression:

$$
f_{C}^{\prime}=P / A
$$

where $f / c$ is the concrete compressive strength (MPa), $P$ is the peak load $(N), A$ is the cross section of the specimen $\left(\mathrm{mm}^{2}\right)$.

\section{Splitting Tensile Strength Test}

The splitting tensile strength test is conducted under the provision of ASTM C496/C496M-11 "Standard Test Method for Splitting Tensile Strength of Cylindrical Concrete Specimens". A diametral compressive force is applied along the axial symmetry of a cylindrical concrete specimen, with $10 \mathrm{~cm}$ diameter and $20 \mathrm{~cm}$ height. The splitting tensile strength of the specimen is calculated using:

$$
f_{\mathrm{sp}}=2 P / \pi L D
$$

where $f_{s p}$ is splitting tensile strength $(\mathrm{MPa}), P$ is maximum applied load ( $N$ ), $L$ is length of the specimen $(\mathrm{mm}), \mathrm{D}$ is diameter $(\mathrm{mm})$.

\section{Modulus of Rupture Test}

The modulus of rupture test is conducted according to ASTM C78/C78M "Standard Test Method for Flexural Strength of Concrete (Using Simple Beam with ThirdPoint Loading)". If fracture occurs in the middle third of the span length, then the Modulus of Rupture is calculated by

$$
f_{r}=P L / b d^{2}
$$

where $f_{r}$ is the modulus of rupture (MPa), $P$ is maximum applied load $(N), L$ is span length $(\mathrm{mm}), b$ is average width of specimen (i.e. $150 \mathrm{~mm}$ ), $d$ is average depth of specimen (i.e. $150 \mathrm{~mm}$ ).

\section{Modulus of Elasticity Test}

The specimen used to test the modulus of elasticity is a cylinder with $150 \mathrm{~mm}$ diameter and $300 \mathrm{~mm}$ height. The standard test for modulus of elasticity refers to ASTM C469 / C469M - 10 "Standard Test Method for Static Modulus of Elasticity and Poisson's Ratio of Concrete in Compression". The modulus of Elasticity can be calculated using:

$$
E=\left(S_{2}-S_{1}\right) /\left(\varepsilon_{2}-0,00005\right)
$$

where $E$ is the Modulus of Elasticity of concrete, $S_{2}$ is the stress at $40 \%$ limit load (MPa), $S_{1}$ is the tension when the strain is $0.00005(\mathrm{MPa})$, and $\varepsilon_{2}$ is the strain at the $40 \%$ limit load.

\section{Mix Design}

Concrete mixtures with no fibers added are designed to achieve the concrete compressive strength of $f / c=$ $30 \mathrm{MPa}$, without the addition of waste plastic banner fiber, while the other 4 concrete mixture proportions are designed for $f / c=30 \mathrm{MPa}$ too, but with the addition of waste plastic banner fiber with percentage $0.25 \%$, $0.5 \%, 1.0 \%$, and $2.0 \%$ of concrete volume. The design slump value is set at $10 \pm 2 \mathrm{~cm}$. The waste plastic banner fiber has aspect ratio of $80(40 \mathrm{~mm}$ length and $0.5 \mathrm{~mm}$ width).

Concrete mixture proportion is designed under the Indonesian provisions of SNI 03-2834-2002, "Provisions for Proportioning Normal Concrete Mixture". The material proportions required per $\mathrm{m}^{3}$ for each fiber percentage, including the weight of fiber, water,

\begin{tabular}{|c|c|c|c|c|c|c|}
\hline Code & $\begin{array}{c}\% \\
\text { fiber }\end{array}$ & $\begin{array}{l}\text { Fiber } \\
(\mathrm{kg})\end{array}$ & $\begin{array}{c}\text { Water } \\
(\mathrm{kg})\end{array}$ & $\begin{array}{c}\text { Cement } \\
(\mathrm{kg})\end{array}$ & $\begin{array}{l}\text { CA } \\
(\mathrm{kg})\end{array}$ & $\begin{array}{l}\text { FA } \\
(\mathrm{kg})\end{array}$ \\
\hline WPFO & 0 & 0 & & & & \\
\hline WPFA & 0.25 & 2 & & & & \\
\hline WPFB & 0.5 & 4 & 170.92 & 432.7 & 814.62 & 836.75 \\
\hline WPFC & 1,0 & 8 & & & & \\
\hline WPFD & 2,0 & 16 & & & & \\
\hline
\end{tabular}
cement, coarse aggregate (CA) and fine aggregate (FA) are shown in the Table 2.

Table 2 Concrete mix design composition

\subsection{RESULTS AND DISCUSSION}

\subsection{Slump Test}

The slump test is used to control the workability of concrete mixtures. The design slump value in mix design is $10 \pm 2 \mathrm{~cm}$. Figure 2 shows the slump values for mixtures with different fiber concentrations.

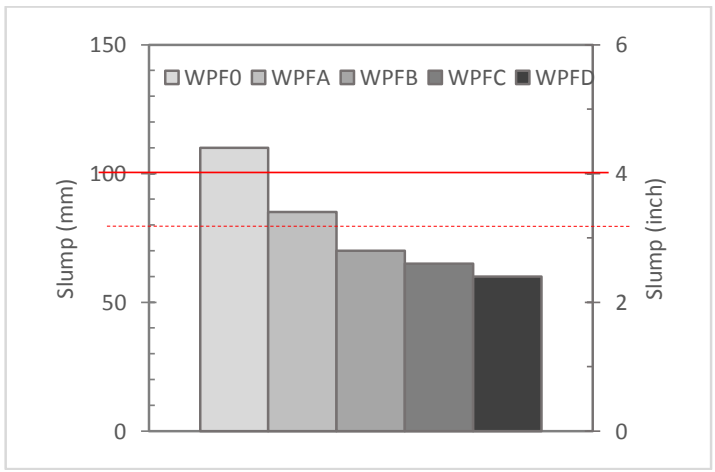

Figure 2 Slump test result 
Figure 2 shows that increasing the fiber concentration will decrease the slump value of the mixtures, indicating that high fiber concentrations make the concrete mixtures difficult to work with. It appears that the slump value continues to decrease to $6 \mathrm{~cm}$ in WPF D. In the WPF A mixture, the slump value is $8.5 \mathrm{~cm}$ which still meets criteria for the design slump value chosen in the mix design procedure. Addition of fiber up to $1 \%$ produces concrete mixture with the slump value of 70 (WPF C) which is below the desired slump value for workable concrete mixture. Thus adding fiber concentration above $1 \%$ is not recommended as it will significantly decrease the workability level of the concrete mixtures. The same result was obtained by Prahallada [7], which used waste plastic fibers comes from plastic pots, buckets, cans, drums and utensils. Prahallada states that the maximum workability is achieved with the addition of $1 \%$ waste plastic fibers. Thirumugan [6] shows the same result while using waste nylon fiber. The addition of waste nylon fiber by $2 \%$ of volume reduce the slump value to $27 \%$. He observed that by adding the nylon fiber show good workability compared with other fiber combinations such as waste lath fiber or combination between lath and nylon fiber.

The addition of waste plastic fiber above 1\% increases the volume of the fiber which causes the mortar of cement paste to become stickier and it hinders the flow of concrete mixture. The waste plastic fibers can also produce fiber aggregation which contributed to the decreasing value of concrete slump. We suggest to limit the percentage of waste plastic banner to $0.5 \%$, to obtain a workable concrete mixture.

\subsection{Compressive Strength}

The compressive strength test was performed using a cylindrical test object $10 \mathrm{~cm}$ in diameter and $20 \mathrm{~cm}$ in height. Tests were performed on test specimens that were 7,14 , and 28 days old. One day prior to the compressive strength test, the specimen is removed from the immersion bath and is left in the dry state for the compressive strength test. Equation (1) is used to obtain the compressive strength, $f^{\prime}{ }_{c}$; the calculated compressive strength is calibrated to a standard test object (cylindrical concrete with $15 \mathrm{~cm}$ in diameter and $30 \mathrm{~cm}$ height), i.e. by multiplying its value to a factor of 1.04. Table 3 shows the result of compressive strength test. Each compression strength test was obtained from nine test specimens, which have standard deviations from 4.40 to $7.92 \mathrm{MPa}$.

Table 3 Compressive strength test result

\begin{tabular}{ccccc}
\hline $\begin{array}{c}\text { Sample } \\
\text { Code }\end{array}$ & $\begin{array}{c}\text { Percent } \\
\text { Fiber (\%) }\end{array}$ & \multicolumn{3}{c}{$\begin{array}{c}\text { Average Compressive } \\
\text { Strength }\end{array}$} \\
\cline { 3 - 5 } & & 7 days & 14 days & 28 days \\
\hline WPF0 & 0 & 31.03 & 31.04 & 33.88 \\
\hline WPFA & 0,25 & 24.86 & 29.46 & 28.28 \\
\hline WPFB & 0,5 & 23.14 & 29.94 & 33.56 \\
\hline WPFC & 1,0 & 23.68 & 32.58 & 35.56 \\
\hline WPFD & 2,0 & 23.11 & 23.94 & 31.04 \\
\hline
\end{tabular}

Figure 3 shows the dependence of the compressive strength of the concrete mixtures with cure time. All mixtures (WPF 0 - WPF D) have similar dependence of the compressive strength with respect to the cure time as those of normal mixtures. Waste plastic banner fiber concrete gain $77 \%$ its compressive strength at the age of 7 days, 14 days reaches $91 \%$ and reaches the ultimate compressive strength at 28 days. In general, the normal concrete mixture reaches $65 \%$ of the compressive strength at 7 days and $88 \%$ at 14 days.

The concrete mixture WPF C, with $1 \%$ waste plastic fibers added, has the highest compressive strength of $35.56 \mathrm{MPa}$, which is $4.95 \%$ higher than the compressive strength of WPF 0 . In contrast, WPF A shows a decrease in the compressive strength by almost $16.5 \%$ compared that of WPF 0. WPF A also produces the smallest compressive strength value compared to other mixtures. Our study shows that adding plastic waste fiber does not give change the compressive strength of the concrete significantly.

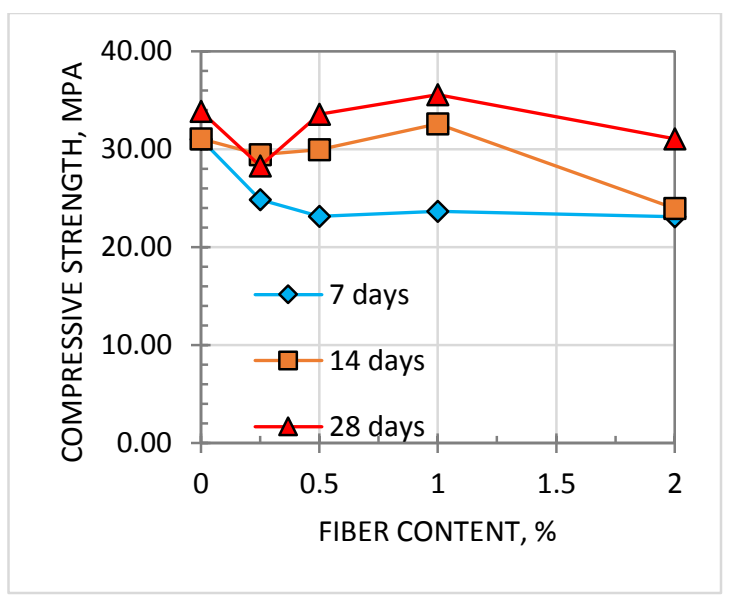

Figure 3 Compressive strength growth

Similar results are shown by Thirumugan [6], the addition of plastic waste fibers from nylon tends to decrease the compressive strength of the concrete. However, mixing nylon waste fibers with lath fibers fairly improve the compressive strength of the concrete. Some researchers added pozzolan to improve the compressive strength of concrete. Du et al. [8] used GGBFS (Ground Granulated Blast Furnace Slag) material to improve compressive strength of fiber reinforced concrete.

\subsection{Splitting Tensile Strength}

The splitting tensile strength test is performed on cylindrical concrete specimens cured at 7, 14 and 28 days. Equation (2) is used to calculate the splitting tensile strength of the specimen. Figure 4 shows the relationship between splitting tensile strength and the waste plastic banner percentage for 7,14 and 28 days specimens. Each splitting tensile strength test was obtained from nine test specimens, which have standard deviations from 0.11 to $0.48 \mathrm{MPa}$. 


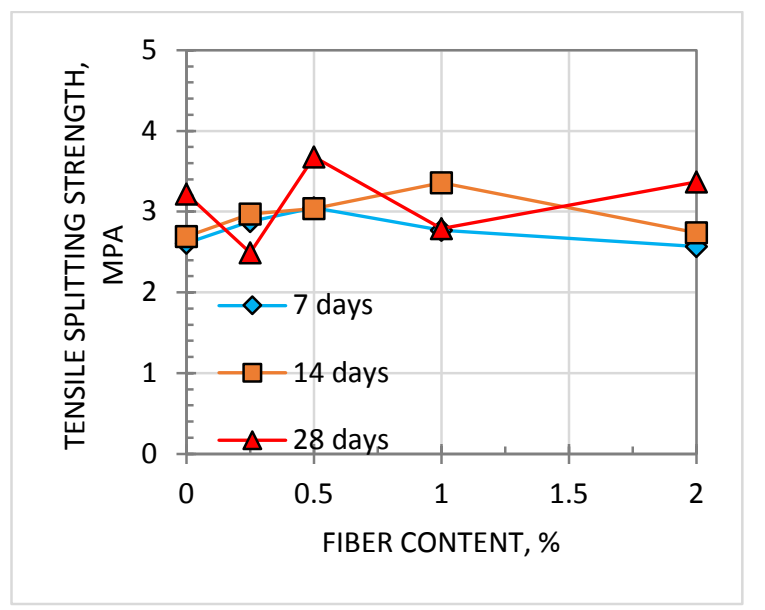

Figure 4 Splitting tensile strength growth

The splitting tensile strength increases with cure time 7 and 14 days for all mixtures. We observed one exception that the splitting tensile strength decreases for WPF A and WPF C at cure time of 28 days. At cure time of 7 days the splitting tensile strength has reached $84.9 \%$ compared to values at 28 days. At the age of 14 days, the splitting tensile strength of the average has reached $92 \%$ of the results at the age of 28 days.

The mixture WPF B, with $0.5 \%$ added fiber, produces the highest splitting tensile strength value of $3.68 \mathrm{MPa}$. This value shows an increase of $14.28 \%$ compared to that of a normal concrete mixture WPF 0.

The addition of more fibers does not increase the tensile strength of concrete. These results are similarly shown by Javali [9] who uses polypropylene plastic fibers. By adding $0.3 \%$ the polypropylene fiber tensile strength of the concrete reaches a maximum value of 3.7 MPa. However, by combining polypropylene fiber with steel fiber, the tensile strength increased to 8.5 MPa [9]. Prahallada [7] suggests similar results, adding $1 \%$ plastic waste fiber gives maximum tensile strength in concrete, but an increase of above $1 \%$ will decrease the tensile strength value.

Taking into account the effect of concrete workability, we recommend adding $0.5 \%$ of the plastic waste fiber to the concrete mix to increase the tensile strength.

\subsection{Modulus of Rupture}

The modulus of rupture of the concrete is obtained from a beam specimen, $15 \mathrm{~cm}$ in height, $15 \mathrm{~cm}$ in width and $60 \mathrm{~cm}$ in length. The beam specimen is tested at the age of 28 days. The experiment uses the three point loading method. The results are tabulated in Table 4. Each modulus of rupture test was obtained from three test specimens, with standard deviations range from 0.11 to $0.47 \mathrm{MPa}$.
Table 4 Modulus of rupture test result

\begin{tabular}{ccc}
\hline Sample Code & $\begin{array}{c}\text { Percent } \\
\text { Fiber (\%) }\end{array}$ & $\begin{array}{c}\text { Modulus of Rupture } \\
(\mathbf{M P a})\end{array}$ \\
\hline WPFO & 0 & 4.13 \\
\hline WPFA & 0.25 & 4.30 \\
\hline WPFB & 0.5 & 4.00 \\
\hline WPFC & 1.0 & 4.15 \\
\hline WPFD & 2.0 & 3.91 \\
\hline
\end{tabular}

It can be seen that WPF A $(0.25 \%$ fiber) shows the highest Modulus of Rupture, which is $4.30 \mathrm{MPa}$, increase about $4.11 \%$ compare to normal mixture. The addition of fibers above $1 \%$ tends to decrease the value of Modulus of Rupture. WPF D, which has $2 \%$ of fiber, shows the smallest Modulus of Rupture, which is $3.91 \mathrm{MPa}$ (decrease about $5.33 \%$ from normal mixture). Similar results are shown by Prahallada [7] which states that the addition of plastic waste fibers above $1 \%$ will lower the Modulus of Rupture of the concrete.

The relationship between compressive strength and Modulus of Rupture can be derived by using the empirical equations in IS 456 "Indian Standard Code of Practice-Plain and Reinforced Concrete" [24], which gives:

$$
f_{r}=0.7 \sqrt{ } f^{\prime} c
$$

Where $f_{r}$ is Modulus of Rupture of concrete (MPa), and $f^{\prime} c$ is concrete compressive strength (MPa). Equation 5 provides a prediction of the flexural strength which is quite close to the experimental flexural strength. Similar results were also obtained by Khan et al., [10]. Figure 5 shows the relationship between the Modulus of Rupture value of the experimental results with the empirical equations developed from is 456. From these results, the empirical relationship between compressive strength and Modulus of Rupture suggested by IS 456 as in (5) can also be used for concrete with plastic waste fiber.

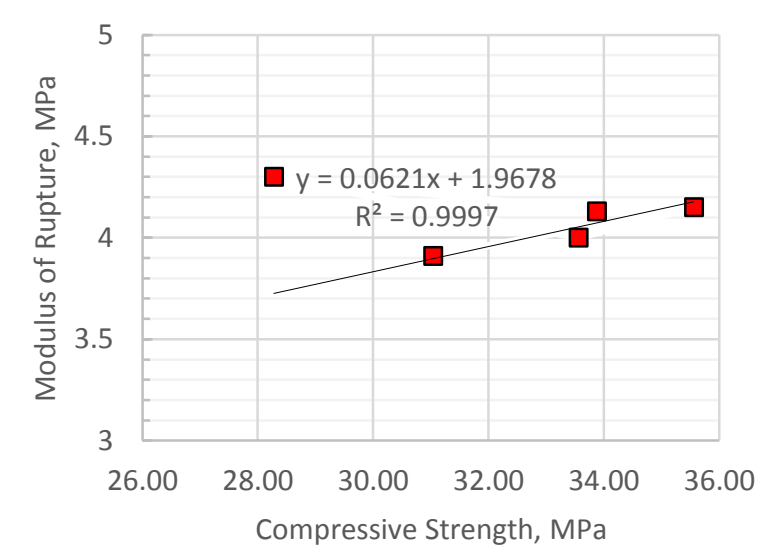

Figure 5 Correlation between compressive strength and modulus of rupture 


\subsection{Modulus of Elasticity}

Modulus of Elasticity is the ratio of normal compressive stress to the corresponding strain below proportional limit of concrete. To obtain the modulus of elasticity value, testing program were done to a 28 days of cylindrical which has a diameter of $15 \mathrm{~cm}$ with a height of $30 \mathrm{~cm}$. Table 5 shows the correlation between fiber percentage and the Modulus of Elasticity.

Table 5 Modulus of Elasticity test result

\begin{tabular}{ccc}
\hline Sample Code & $\begin{array}{c}\text { Percent } \\
\text { Fiber (\%) }\end{array}$ & $\begin{array}{c}\text { Modulus of Elasticity } \\
\text { (MPa) }\end{array}$ \\
\hline WPFO & 0 & 20,558 \\
\hline WPFA & 0.25 & 22,418 \\
\hline WPFB & 0.5 & 23,025 \\
\hline WPFC & 1.0 & 20,719 \\
\hline WPFD & 2.0 & 21,506 \\
\hline
\end{tabular}

From the table it can be seen that in general the addition of flex banner waste fiber can increase the value of the Modulus of Elasticity of concrete. A mixture of WPF B which has a flex banner waste fiber content of $0.5 \%$ shows the highest Elasticity Modulus value of $23,025 \mathrm{MPa}$. This value shows an increase of $12 \%$ over the normal mix, WPF 0 , which does not contain flex banner waste fiber.

We proposed the relationship between the compressive strength and the Modulus of Rupture, derived by using the modified empirical equations in $\mathrm{ACl}$ 318-11 "Building Code Requirements for Structural Concrete" [20], to give:

$$
E_{C}=\alpha 4,700 \sqrt{ } f^{\prime}{ }_{C}
$$

Where $E_{c}$ is the Modulus of Elasticity (MPa), $f^{\prime} c$ is the concrete compressive strength (MPa), and $\alpha$ is the modification factor which is taken 0.82 .

The coefficient $\alpha$ is chosen to give the predicted value closest to the experimental Modulus of Elasticity. Figure 6 shows the relationship between the compressive strength with the value of Modulus of Elasticity. The value of Modulus of Elasticity shown is the value of the experimental result, the result of the $\mathrm{ACl}$ 318-11 empirical equation, and the result of the modified ACl 318-11 equation (Eq. (6)).

The regression analysis was conducted to determine the accuracy of the proposed empirical equations. From the results of regression analysis, coefficient of determination obtained is equal to $R^{2}=$ 0.9997.

This result is closely approximated by Khan et.al [10] which uses the empirical equation of IS 456, which states the relationship between compressive strength with Modulus of Elasticity expressed by the equation $E_{c}$ $=5,000 \sqrt{ } f^{\prime}$, which yields $R^{2}=0.610$.

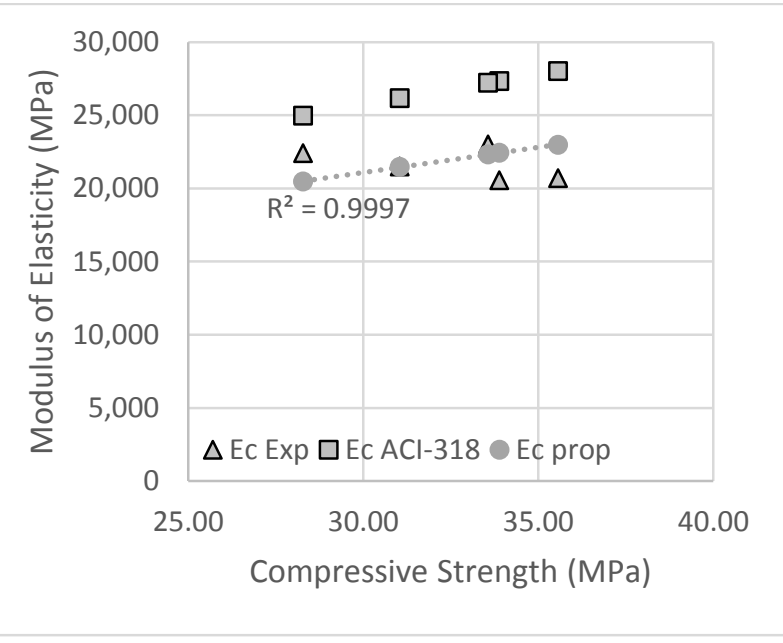

Figure 6 Correlation between compressive strength and modulus of elasticity

\subsection{CONCLUSION}

In general the additional of waste plastic banner fibers can improve the mechanical properties of hardened concrete, including its compressive strength, splitting tensile strength, Modulus of Elasticity and Modulus of Rupture. The optimum mechanical properties of hardened concrete is achieved by the addition of waste plastic fiber $0.5-1.0 \%$ of the volume of concrete mixture. Adding waste plastic banner fiber above $1.0 \%$ will decrease the workability of fresh concrete which causes the concrete mix to become hard and is difficult to cast. In the end, the use of waste plastic banners as a concrete mixture is expected to reduce the level of environmental pollution by plastic waste.

\section{Acknowledgement}

The authors gratefully acknowledge the support by the Ministry of Research, Technology and Higher Education for this work under "Penelitian Produk Terapan Grant" No. 1598/K4/KM/2017.

\section{References}

[1] Rao, N. S., Rao, P. R. M., and P. Jagadeesh. 2016. Experimental Evaluation of Strength Properties of Steel Fibre Reinforced Concrete. Asian Journal of Civil Engineering (BHRC). 17(4): 487-494.

[2] Hassan, H. F. 2015. Experimental Study of Fibrous High Strength Self-Compacting Concrete One Way Slabs. Journal of Engineering and Development. 19(1): 50-67.

[3] Rao, M. V., Murthy, N. R., and Kumar, V. S. 2011 . Behaviour of Polypropylene Fibre Reinforced Fly Ash Concrete Deep Beams in Flexure and Shear. Asian Journal of Civil Engineering (BHRC). 12(2): 143-154.

[4] Pawar, A. S., Dabhekar, K. R. 2014. Feasibility Study of Concrete Based Pavement by Using Fibers \& Cementing Waste Materials. International Journal of Research in 
Engineering and Technology. 3(5): 76-78. https://doi.org/10.15623/ijret.2014.0305015.

[5] Setiawan, A., Hidayat, I. 2013. Experimental Study on Epoxy Polystyrene as a Partial Substitution of Fine Aggregate of Concrete Mixture. Asian Journal of Civil Engineering (BHRC). 14(6): 849-858.

[6] Thirumurugan, A., Sivaraja, M. 2013. Workability and Strength Properties of Hybrid Fibre Reinforced Concrete from Industrial Waste. Asian Journal of Civil Engineering (BHRC). 14 (3): 477-485.

[7] Prahallada, M. C., Prakash, K. B. 2012. Strength and Workability Characteristics of Waste Plastic Fibre Reinforced Concrete Produced From Recycled Aggregates. International Journal of Engineering Research and Application. 1(4): 1791-1802.

[8] Du, H., and Tan, K. H. 2014. Concrete with Recycled Glass as Fine Aggregate. ACl Materials Journal. 111 (1): 47-57. https://doi.org/10.14359/51686446.

[9] Javali, P. N., Elavenil, S. 2015. Mechanical Properties of Concrete Reinforced With Steel-Polypropylene Hybrid Fibers. Journal on Structural Engineering. 4(2): 22-27.

[10] Khan, S., Khan, R. A., Islam, S., Khan, R. A. 2016. Interrelationship of Properties of PPFRC. International Journal of Reserach in Advent Technology. 4(3): 24-29.

[11] Nili, M., Afroughsabet, V. 2012. The Long-term Compressive Strength and Durability Properties of Silica Fume FibreReinforced Concrete. Materials Science and Engineering Journal. 531: 107-111. https://doi.org/10.1016/j.msea.2011.10.042.

[12] Vaidhyanathan, S. N., Thenmozhi, R., Babu, B. R. 2017. Experimental Study on the Mechanical Properties of Light Weight Fly Ash Aggregate Concrete Reinforced with Steel Fiber. SSRG International Journal of Civil Engineering. April 2017: 420-424.
[13] Choure, A., Chandak, R. 2017. Experimental Study on Concrete Containing Fly Ash. International Research Journal of Engineering and Technology. 4(2): 202-205.

[14] Vrettos, I., Kefala, E., Triantafillou, T. C. 2013. Innovative Flexural Strengthening of Reinforced Concrete Columns Using Carbon-Fiber Anchors. ACI Structural Journal. 110(1): 63-70.

[15] Xia, J., Mackie, K. 2014. Axisymmetric Fiber Orientation Distribution of Short Straight Fiber in Fiber-Reinforced Concrete. ACI Materials Journal. 111 (2): 133-142. https://doi.org/10.14359/51686721.

[16] Vijai, K., Kumutha, R., and Vishnuram, B. G. 2012. Properties of Glass Fibre Reinforced Geopolymer Concrete Composites. Asian Journal of Civil Engineering (BHRC). 4(13): 51 1-520.

[17] Hasooun, M. N., and Manaseer A. A. 2005. Structure Concrete Theory and Design. 2nd edition. John Wiley \& Sons Inc.

[18] Nawy, E. G. 2005. Reinforced Concrete a Fundamental Approach. 5th edition. New Jersey: Pearson Education Inc.

[19] Nilson, A. H., Darwin, D., and Dolan, C. W. 2003. Design of Concrete Structures. 13th edition. Mc Graw Hill, Singapore.

[20] $\mathrm{ACl} 318 \mathrm{M}-11$, Building Code Requirements for Structural Concrete

[21] ASTM C39 / C39M - 09a, Standard Test Method for Compressive Strength of Cylindrical Concrete Specimens,

[22] ASTM C496/C496M-11, Standard Test Method for Splitting Tensile Strength of Cylindrical Concrete Specimens"

[23] ASTM C78/C78M, Standard Test Method for Flexural Strength of Concrete (Using Simple Beam with Third-Point Loading).

[24] ASTM C469 / C469M - 10, Standard Test Method for Static Modulus of Elasticity and Poisson's Ratio of Concrete in Compression. 